\title{
REPRESENTASI FRAME DALAM LATAR BELAKANG WACANA TAJUK TENTANG TERORISME
}

\author{
P. Ari Subagyo \\ Fakultas Sastra Universitas Sanata Dharma Yogyakarta \\ email: parisana@usd.ac.id
}

\begin{abstract}
Abstrak
Penelitian ini bertujuan mendeskripsikan representasi frame dalam latar belakang editorial (tajuk) tentang terorisme. Kajian ini menggunakan pendekatan pragmatik kritis, yakni paduan antara pragmatik dan analisis wacana kritis (AWK). Ada tiga frame dalam wacana tajuk tentang terorisme dalam empat surat kabar nasional (Suara Pembaruan, Republika, Kompas, dan Koran Tempo) yang selaras dengan ideologi (latar historis dan afiliasi) media massa. Penelitian ini membuktikan bahwa tiga frame tersebut terepresentasi secara sistematis ke dalam latar belakang editorial tentang terorisme. Surat kabar Suara Pembaruan, Republika, Kompas, dan Koran Tempo merepresentasikan frame mereka dengan caranya masing-masing. Cara yang dimaksud adalah menggunakan bagian latar belakang untuk mengemukakan informasi atau opini yang selaras dengan frame masing-masing.
\end{abstract}

Kata kunci: representasi, frame, latar belakang, editorial, pragmatik kritis

\section{THE REPRESENTATIONS OF FRAMES IN THE BACKGROUNDS OF EDITORIALS ON TERRORISM}

\begin{abstract}
This study aims to describe the representations of frames in the backgrounds of editorials on terrorism. It uses the critical pragmatic approach combining pragmatics and critical discourse analysis (CDA). There are three frames in the editorials on terrorism in four national dailies in Indonesia (Suara Pembaruan, Republika, Kompas, and Koran Tempo) in accordance with their ideologies (historical backgrounds and affiliations). The study proves that the three frames are systematically represented in the backgrounds of editorials on terrorism. Suara Pembaruan, Republika, Kompas, and Koran Tempo represent their frames in their own ways. Each daily uses the background to present information or opinions according to its frame.
\end{abstract}

Keywords: representation, frame, background, editorial, critical pragmatics

\section{PENDAHULUAN}

Frame adalah pengetahuan tentang konsep (knowledge about concept) (Renkema, 2004: 236; bdk. Fairclough, 2010: 182). Segala sesuatu yang diketahui manusia tentang realitas atau dunia bergantung pada bagaimana manusia membingkai (mengkonstruksi dan menafsirkan) dunia (Edelman, 1993 dikutip Eriyanto, 2002: 155). Karena itu, tidak mengherankan jika suatu realitas yang sama dapat dipahami secara berbeda bila dikonstruksi dengan frame yang berbeda. Sebuah perang, misalnya, dapat dikatakan sebagai perjuangan suci, tetapi dapat pula disebut agresi. Apabila dijumbuhkan dengan gagasan van Dijk (2005: 79; 2006: 98), frame tidak lain merupakan kognisi (cognition), khususnya kognisi institusional (institutional cognition), yang menentukan proses pembuatan dan pemahaman wacana. 
Dalam praktik media massa, frame merupakan transformasi atau turunan ideologi yang terepresentasi dalam struktur dan penggunaan bahasa pada wacana berita maupun editorial (bdk. Fairclough, 2010: 57-58). Frame dalam editorial tampak lebih jelas daripada dalam berita. Fairclough (1995: 100-101), misalnya, mencontohkan frame harian Inggris Sun dan Guardian Weekly dalam membingkai Saddam Hussein dan George Bush Sr. Sun melecehkan Saddam dengan sebutan a madman (orang gila), a menace to peace (ancaman perdamaian), a tyrant (tiran), a terrorist (teroris), dan a blusterer (peniup badai). Di pihak lain, Guardian Weekly justru menegasikan Presiden George Bush dengan menyatakan "Mr. Bush's likely desire to settle accounts before leaving office" ('Mr Bush enggan turun dari kursi kekuasaannya').

Frame mempresentasikan sikap surat kabar atas isu tertentu, lalu sikap itu terwujud sebagai fenomena bahasa (bdk. Fairclough, 2010: 57-58). Frame tentang terorisme berarti bingkai yang digunakan dalam melihat fenomena terorisme. Menurut temuan Subagyo dan Adji (2014), dalam wacana tajuk tentang terorisme (WTT) 2002-2013 dijumpai tiga frame. Pertama, Suara Pembaruan menggunakan frame "Dalang teror adalah Jemaah Islamiyah dan jaringannya; motifnya melakukan kekerasan dengan mengatasnamakan Islam." Kedua, Republika menggunakan frame "Dalang teror ialah intelijen Amerika Serikat dan sekutunya; motifnya menguasai sumber daya alam Indonesia dengan memojokkan Islam." Adapun Kompas dan Koran Tempo menggunakan frame "Dalang teror misterius; penanganan lebih penting."

Adapun yang dimaksud latar belakang adalah bagian WTT yang oleh Bolivar (1994: 281) disebut sebagai Situasi (Situation). Menurut Bolivar, Situasi berada di awal tajuk dan berfungsi untuk mengacu peristiwa atau persoalan yang sedang menjadi pembicaraan khalayak. Namun, fungsi Situasi sesungguhnya lebih dari itu. Informasi di dalamnya merupakan latar belakang yang menjadi informasi lama (old information) ataudalam perspektif kalimat fungsional Mathesius (Sampson, 1980: 104)-ibarat tonggak (peg) untuk mengaitkan informasi baru (new information). Karena WTT ditujukan untuk beropini, besar kemungkinan latar belakang pun memuat opini. Masalah yang akan dijawab lewat artikel ini adalah bagaimana representasi frame dalam latar belakang WTT?

Penting dicatat bahwa wacana tajuk pada umumnya, dan WTT khususnya, merupakan fenomena bahasa yang selama ini terlepas dari perhatian, baik bagi pembaca maupun peneliti. Dalam hal terabaikannya wacana tajuk dari pembaca, Koesworo, Margantoro, dan Viko (1994: 111) menulis "Wacana tajuk rencana di media massa mana pun termasuk jenis tulisan yang tidak populer dan hanya memiliki sedikit pembaca". Adapun tentang terlepasnya wacana tajuk (editorial) dari perhatian para peneliti, van Dijk (1995b: 1) menyatakan, "Many phenomena of everyday life tend to be ignored by scholars.... Editorials are no exception".

Pernyataan van Dijk tersebut terbukti dari ketiadaan kajian atas WTT di berbagai jurnal ilmiah. Sekadar contoh, dua artikel tentang wacana terorisme yang ditulis oleh Salama maupun Oddo tidak membahas tentang WTT. Salama (2011) dalam artikel "Ideological Collocation and the Recontexuali-zation of WahhabiSaudi Islam Post-9/11: A Synergy of Corpus Linguistics and Critical Discourse Analysis" menelaah bagaimana ideologi yang bertentangan diaktualisasikan menjadi kolokasi dalam wacana-wacana tentang Islam Wahhabi (Wahhabisme) sejak "tagedy 9/11". Adapun dalam artikel berjudul "War Legitimation Discourse: Representing 'Us' and 'Them' in Four US Presidential Addresses", Oddo (2011) 
mengkaji penggunaan us ('kita') dan them ('mereka') dalam empat pidato dua presiden Amerika Serikat (F.D. Roosevelt dan G.W. Bush).

Jika wacana tajuk (termasuk WTT) dipahami sebagai wacana argumentasi, pun belum ada penelitian yang secara khusus mengkaji bagian latar belakang. Artikel Ardianto (2015) yang berjudul "Struktur Argumen dalam Wacana Karya Tulis Ilmiah Mahasiswa", misalnya, sebatas menelaah struktur argumen dalam wacana argumentatif di luar wacana tajuk. Padahal, di pihak lain, fenomena kebahasaan dalam wacana tajuk (termasuk dalam WTT) merepresentasikan sikap dan "ideologi" pengelola surat kabar atas fenomena tertentu dalam masyarakat, atau dalam hal ini tentang terorisme di Indonesia.

\section{METODE}

Objek penelitian ini berupa bagian latar belakang WTT. Data diambil dari WTT mengenai bom Bali I (14 Oktober 2002) hingga fenomena terorisme paling mutakhir di Indonesia (tahun 2013). Perlu dicatat, sejak eksekusi mati Amrozi, Imam Samudra, dan Mukhlas pada 9 November 2008, lalu disusul tertangkapnya para gembong terorisme, aksi yang melibatkan Jemaah Islamiyah dan Al Qaeda praktis telah berubah bentuk. Gejala terbaru sejak pertengahan 2014 ialah Islamic State of Iraq and Syria (ISIS) sebagai bentuk mutakhir perlawanan kepada Barat.

Penelitian ini dilakukan dengan pendekatan pragmatik kritis sebagai paduan pragmatik dengan analisis wacana kritis (bdk. Subagyo, 2010). Metode analisis data yang diterapkan dalam kajian ini mencakup metode padan pragmatik dan model analisis kognisi sosial.

Metode padan adalah metode analisis dengan alat penentu di luar, terlepas, dan tidak menjadi bagian dari bahasa (langue) yang bersangkutan (Sudaryanto, 2015: 15). Metode padan pragmatik adalah subjenis metode padan yang alat penentunya orang yang menjadi mitra wicara (ibid., hlm. 1718). Dengan metode ini-dan sesuai saran Leech (1983: 13) - peneliti menempatkan diri sebagai penerima tutur yang menafsirkan WTT. Adapun metode analisis kognisi sosial yang ditawarkan van Dijk (1995a, 2006; 2010) memahami wacana sebagai bangunan tiga dimensi, yaitu (a) teks, (b) kognisi sosial, dan (c) konteks. Pada dimensi teks, diidentifikasi bagian teks WTT (dalam hal ini latar belakang) yang digunakan untuk merepresentasikan frame. Pada dimensi kognisi sosial, dikupas proses produksi teks yang melibatkan kognisi institusional pengelola surat kabar sebagai lembaga media. Adapun pada dimensi konteks, ditelaah representasi frame dalam latar belakang WTT.

\section{HASIL PENELITIAN DAN PEMBA- HASAN}

Jika dikaitkan dengan penalaran Ardianto (2015: 2), kajian ini menyangkut ketepatan pemanfaatan struktur argumen dalam bagian latar belakang WTT. Karena pada dasarnya WTT berisi opini (pendapat) tentang fenomena terorisme di Indonesia, bagian latar belakang WTT juga memuat tonggak ( $p e g$ ) argumentasi untuk dasar atau pondasi bagi argumen pada bagian-bagian selanjutnya. Telah dikemukakan pada Pendahuluan bahwa Subagyo dan Adji (2014) menemukan tiga frame dalam WTT. Lalu, bagaimana representasi tiga frame tersebut dalam latar belakang WTT? Berikut ini paparan dan penjelasannya.

\section{Representasi Frame dalam Latar Bela- kang WTT Suara Pembaruan}

Suara Pembaruan menggunakan bingkai "Dalang teror adalah Jemaah Islamiyah dan jaringannya; motifnya melakukan kekerasan dengan mengatas-namakan Islam". Secara konsisten Suara Pembaruan memanfaatkan bagian latar belakang sejumlah WTT-nya sebagai representasi 
frame dengan mengemukakan informasi dan opini tentang (a) Indonesia menjadi korban terorisme, (b) kebiadaban aksi teror dan dampak ledakan, (c) isyarat tentang pelaku teror, serta (d) Azahari dan Amrozi, dkk. sebagai teroris.

\section{Indonesia Menjadi Korban Terorisme}

Suara Pembaruan memanfaatkan latar belakang WTT 14 dan 21 Oktober 2002 untuk merepresentasikan frame dengan mengemukakan informasi dan opini bahwa Indonesia menjadi korban terorisme. (Garis bawah ditambahkan)

(1) Ada satu hal yang selama ini terlupakan ketika bicara soal terorisme. Apa pun tuduhan yang pernah disampaikan kepada Indonesia tentang dugaan dan kemungkinan keterkaitan dengan organisasi teroris internasional, kita sering melupakan bahwa sebenarnya sudah sejak lama Indonesia menjadi korban dari ulah terorisme itu sendiri.

Peristiwa Poso dan Maluku adalah salah satu manifestasi terorisme. Peledakan-peledakan dan seranganserangan terhadap gereja, mesjid, bahkan Candi Borobudur dan rumah-rumah ibadah lainnya, serta kerusuhan antarsuku lainnya, adalah manifestasi terorisme yang telah mengemuka di Indonesia sejak beberapa tahun terakhir. (Suara Pembaruan, 14/10/2002)

(2) Kita telah menjadi korban terorisme. Tetapi, kenapa secara internasional kita sepertinya tidak diperlakukan sebagai korban yang patut memperoleh simpati dan dukungan? Terasa pula betapa nuansa pemberitaan media asing tentang Tragedi 12 Oktober di Legian sangat berbeda dengan nuansa pemberitaan Tragedi 11 September di New York, Washington DC, dan Pennsylvania.

Pemerintah RI pun telah mulai merasa jengah dengan sikap dunia terhadap Tragedi 12 Oktober. Singkatnya, Pe- merintah menuntut negara-negara lain agar adil memperlakukan Indonesia yang telah menjadi korban terorisme. (Suara Pembaruan, 21/10/2002)

Dalam kutipan (1), dinyatakan bahwa sudah sejak lama Indonesia menjadi korban terorisme. Kemudian disebutkan peristiwa Poso dan Maluku serta peledakan dan serangan rumah-rumah ibadah sebagai bukti. Selain itu, semua informasi tersebut juga menegaskan bahwa terorisme memang sungguh ada di Indonesia. Dalam kutipan (2), dikemukakan kembali bahwa Indonesia menjadi korban terorisme sehingga tak selayaknya diperlakukan tidak adil oleh media massa dan negara-negara lain.

\section{Kebiadaban Pelaku Teror dan Dampak Ledakan}

Informasi dan opini tentang kebiadaban aksi teror dan dampak ledakan dalam latar belakang WTT bisa membangun opini bahwa pelakunya amat kejam.

(3) Tidak bisa dibantah, dengan pengeboman yang dahsyat dan sangat keji serta biadab di Legian, Kuta, Bali Sabtu (12/10/2002) malam lalu, citra Indonesia yang sudah terpuruk selama beberapa tahun terakhir makin terpuruk. Rasanya sudah sangat sulit dan dibutuhkan waktu yang lama untuk memulihkan kepercayaan masyarakat, terutama para investor asing, untuk menanamkan modalnya di Indonesia. Juga country risk Indonesia sebagai tujuan investasi akan semakin tinggi. Dengan sendirinya pula upaya pemulihan ekonomi yang terpuruk selama ini akan makin berat. (Suara Pembaruan, 16/10/2002)

(4) Tindakan kebiadaban dan kebrutalan kembali terjadi justru dalam suasana masih berlangsungnya Sidang Tahunan, yang konon menghambur-hamburkan uang rakyat. Dan kita terkejut, tiba-tiba sebuah ledakan bom dengan 
kekuatan besar mengguncang Indonesia. Kali ini terjadi di hotel berbintang lima JW Marriott di kawasan Mega Kuningan, Jakarta Selatan, Selasa (5/8). Ini adalah ledakan terdahsyat dan keempat yang mengguncang wilayah ibukota Jakarta dalam tahun 2003. Pihak kepolisian memperkirakan bahwa bom ini dioperasikan dengan cara yang mirip dengan ledakan bom yang mengguncang kawasan Kuta, Bali. (Suara Pembaruan, 6/8/2003)

(5) Tragedi bom di Hotel JW Marriott, Jakarta, menyisakan banyak duka dan keprihatin-an bagi bangsa Indonesia. Kita ingin segera mengetahui apa motif dan siapa pelaku tindakan biadab yang mengakibatkan jatuhnya banyak korban dan bisa berdampak buruk bagi perekonomian. Beberapa indikator ekonomi makro Indonesia yang belakangan ini sudah menunjukkan angka-angka yang melegakan, bisa terancam dengan adanya bom tersebut. Semoga yang dikatakan Menko Perekonomian Dorodjatun KuntjoroJakti bahwa perokonomian Indonesia bisa mengatasi dampak bom Marriott bisa terbukti. Kita sudah lelah dengan krisis yang berkepanjangan. Ketika krisis itu sudah akan berakhir, cobaan kembali melanda bangsa ini. (Suara Pembaruan, 7/8/2003)

(6) Indonesia kembali dilukai oleh tindakan kebiadaban. Kali ini kebiadaban itu tampil dalam wujud membunuh manusia dengan meledakkan bom di Jimbaran dan Kuta, Bali. Teror bom melalui tindakan bunuh diri ini terjadi di tengah keramaian pada Sabtu (1/10) malam, dan menewaskan sedikitnya 26 orang, serta melukai puluhan lainnya. Kita semua berduka atas kebiadaban itu. (Suara Pembaruan, 3/10/2005)

Dalam kutipan (3), Suara Pembaruan mengutarakan tentang kedahsyatan, kekejian, dan kebiadaban pengeboman di Legian. Akibatnya, citra Indonesia semakin terpuruk. Indonesia juga menjadi negara berisiko tinggi untuk berinvestasi. Kutipan (4) mengemukakan kebiadaban dan kebrutalan aksi teror bom di Hotel Marriott. Suara Pembaruan menyebutnya sebagai ledakan terdahsyat dan keempat yang mengguncang wilayah ibukota Jakarta dalam tahun 2003. Sebutan itu merepresentasikan kedahsyaratan dan keberulangan. Dalam kutipan (5) dikemukakan dampak ledakan bom di Hotel Marriott berupa kedukaan dan keprihatinan, terutama dalam bidang ekonomi. Ledakan bom berpotensi mengancam ekonomi makro Indonesia dan memperpanjang krisis bangsa Indonesia. Adapun dalam (6) diutarakan kebiadaban aksi teror bom di Jimbaran dan Kuta, 1 Oktober 2005 (bom Bali II), termasuk jumlah korban tewas 26 orang.

\section{Isyarat tentang Pelaku Teror}

Suara Pembaruan menempatkan JI dan jaringannya sebagai dalang teror bom di Indonesia. Meskipun tidak disebutkan secara literal, isyarat siapa pelaku teror beberapa kali disebutkan.

(7) Tindakan kebiadaban dan kebrutalan kembali terjadi justru dalam suasana masih berlangsungnya Sidang Tahunan, yang konon menghambur-hamburkan uang rakyat. Dan kita terkejut, tiba-tiba sebuah ledakan bom dengan kekuatan besar mengguncang Indonesia. Kali ini terjadi di hotel berbintang lima JW Marriott di kawasan Mega Kuningan, Jakarta Selatan, Selasa (5/8). Ini adalah ledakan terdahsyat dan keempat yang mengguncang wilayah ibukota Jakarta dalam tahun 2003. Pihak kepolisian memperkirakan bahwa bom ini dioperasikan dengan cara yang mirip dengan ledakan bom yang mengguncang kawasan Kuta, Bali. (Suara Pembaruan, 6/8/2003)

(8) Teroris kembali beraksi di Indonesia. Kali ini ledakan dahsyat terjadi di depan Kedutaan Besar Australia 
di Indonesia yang berada di Jalan Rasuna Said, Jakarta Selatan, Kamis (9/9) siang. Sampai hari ini sedikitnya tujuh orang meninggal dan seratus lebih terluka. Hampir semua korban adalah warga negara Indonesia. Aksi penyebar kepanikan ini menunjukkan bahwa organisasi didukung jaringan yang luas. Aksi teror yang besar yang masih segar dalam ingatan adalah ledakan dahsyat di Kuta, Bali, 12 Oktober 2002. Sepuluh bulan kemudian terjadi lagi di Hotel JW Marriott, Jakarta, 5 Agustus 2003, dan 13 bulan setelah itu di depan Kedubes Australia. (Suara Pembaruan, 10/9/2004)

(9) Indonesia kembali dilukai oleh tindakan kebiadaban. Kali ini kebiadaban itu tampil dalam wujud membunuh manusia dengan meledakkan bom di Jimbaran dan Kuta, Bali. Teror bom melalui tindakan bunuh diri ini terjadi di tengah keramaian pada Sabtu (1/10) malam, dan menewaskan sedikitnya 26 orang, serta melukai puluhan lainnya. Kita semua berduka atas kebiadaban itu.

Ini adalah teror bom yang kesekian kali, setelah bom di bursa efek Jakarta, di Bali, kemudian bom di Hotel JW Marriott, Jakarta, di depan Kedutaan Besar Australia di Jakarta, di Tentena, Sulawesi Tengah, dan di beberapa tempat lainnya. Ini juga merupakan rentetan teror yang menggunakan metode bunuh diri sebagai modusnya, seperti yang diduga pada ledakan di depan Kedubes Australia. (Suara Pembaruan, 3/10/2005)

Dalam (7), selain diutarakan biadab dan brutalnya tindakan teror bom di Hotel J.W. Marriott, secara tidak literal dikemukakan pelaku aksi teror lewat pernyataan Pihak kepolisian memperkirakan bahwa bom ini dioperasikan dengan cara yang mirip dengan ledakan bom yang mengguncang kawasan Kuta, Bali. Karena bom dioperasikan dengan cara yang mirip dengan ledakan bom Bali I, berarti pelaku (dan perancangnya) juga mirip, yaitu JI dan jaringannya. Apalagi, para tersangka pelaku bom Bali I (Amrozi, Ali Ghufron, dan Imam Samudra) sudah tertangkap dan disidangkan sehingga sosok pelakunya sudah jelas.

Pernyataan lebih literal dikemukakan Suara Pembaruan dalam (8). JI dan jaringannya ditampilkan lewat pernyataan Aksi penyebar kepanikan ini menunjukkan bahwa organisasi didukung jaringan yang luas. Yang dimaksud dengan "organisasi didukung jaringan yang luas" tentu saja JI dan jaringannya. Setelah pernyataan itu, oleh Suara Pembaruan diingatkan tentang aksiaksi teror besar yang masih segar dalam ingatan, yaitu ledakan dahsyat di Kuta, Bali (12 Oktober 2002), teror bom di Hotel J.W. Marriott, Jakarta (5 Agustus 2003), dan peledakan bom di depan Kedubes Australia (9 September 2004) yang ditanggapi dengan WTT dengan latar belakang (8). Pengingatan itu untuk mempertegas adanya jaringan yang luas.

Adapun penyebutan pelaku teror secara tidak literal dan penggunaan analogi kembali dilakukan oleh Suara Pembaruan dalam (9) sewaktu menanggapi bom Bali II (1 Oktober 2005). Informasi sekaligus opini itu terungkap dalam pernyataan Ini juga merupakan rentetan teror yang menggunakan metode bunuh diri sebagai modusnya, seperti yang diduga pada ledakan di depan Kedubes Australia. Karena modusnya sama, yaitu menggunakan metode bunuh diri, pelaku teror bom Bali II patut diduga sama dengan pelaku peledakan di depan Kedubes Australia. Dalam pandangan Suara Pembaruan, pelaku yang dimaksud tentulah anggota JI dan jaringannya.

\section{Azahari serta Amrozi, dkk. sebagai Tero- ris}

Suara Pembaruan begitu yakin bahwa Azahari sebagai gembong teroris. Semua teror bom di Indonesia sejak bom malam Natal 1999 hingga bom di Jimbaran (bom 
Bali II, 1 Oktober 2005) dilakukan oleh Azahari dan jaringannya (JI). Oleh sebab itu, ketika menanggapi penggerebegan dan tewasnya Azahari (9 November 2005), dalam latar belakang WTT 12 November 2005 dinyatakan:

(10) Doktor Azahari dan Noordin Mohd Top adalah gembong teroris di Indonesia. Dua warga negara Malaysia itu bersama jaringannya di Indonesia merupakan otak peledakan bom di sejumlah daerah. Aksi anti-kemanusiaan mereka dimulai pada malam Natal tahun 1999 dan tahun baru 2000. Ledakan besar yang diduga kuat mereka buat adalah bom di Bali (12/10/2002), bom di Hotel JW Marriott, Jakarta (9/9/2003), bom di Kuningan, Jakarta (5/8/2004) dan bom di Jimbaran, Bali (1/10/2005). (Suara Pembaruan, 12/11/2005)

Suara Pembaruan meyakini Amrozi, dkk. sebagai teroris dan pelaku bom Bali I. Mereka bagian dari jaringan terorisme yang dipimpin Dr. Azahari dan Noordin Mohd Top. Karena itu, saat beropini tentang eksekusi hukuman mati Amrozi, dkk. (9 November 2008), Suara Pembaruan menempatkan diri sebagai keluarga korban, dan menyatakan bahwa eksekusi telah lama dinantikan.

(11) Eksekusi mati terhadap tiga terpidana mati kasus Bom Bali I, yakni Amrozi, Mukhlas, dan Imam Samudra, menyita perhatian kita semua. Maklum, tragedi bom di kawasan wisata Bali, pada 12 Oktober 2002 itu merenggut nyawa 202 orang, termasuk warga asing yang sebagian besar dari Australia.

Oleh karena itu, berlarut-larutnya pelaksanaan eksekusi sempat membuat geram keluarga korban, baik di Bali maupun Australia. Setelah lama dinantikan, akhirnya eksekusi terlaksana. (Suara Pembaruan, 10/11/2008)

\section{Representasi Frame dalam Latar Bela- kang WTT Republika}

Republika menggunakan frame "Dalang teror adalah intelijen AS dan sekutunya; motifnya menguasai sumber daya alam Indonesia dengan memojokkan Islam." Frame tersebut terepresentasi dalam latar belakang beberapa WTT-nya dengan menyajikan informasi dan opini tentang (a) tudingan terhadap JI, (b) kebiadaban pelaku teror dan dampak ledakan, (c) rekayasa intelijen dan pihak asing, serta (d) simpati kepada Ba'asyir serta Amrozi, dkk.

\section{Tudingan terhadap Jemaah Islamiyah}

Sejak menanggapi peristiwa bom Bali I (12 Oktober 2002), lewat WTT edisi 14 dan 26 Oktober 2002, Republika telah menampilkan latar belakang yang merepresentasikan frame-nya, yakni JI telah dijadikan "kambing hitam".

(12) .... Seperti biasa, reaksi segera muncul dari berbagai kalangan, baik dari dalam maupun luar negeri. Dan, di antara reaksi itu adalah tudingan terhadap "kambing hitam" di balik teror yang sangat tidak berperikemanusiaan itu. Menlu Australia Alexander Downer langsung mencurigai Alqaidah, dan bahkan sempat menyebut Jemaah Islamiyah (JI), sebuah organisasi yang oleh kalangan Barat belakangan disebut-sebut terkait dengan jaringan kelompok Islam garis keras pimpinan Usamah bin Ladin tersebut. (Republika, 14/10/2002)

(13) Kalau ada sebuah nama yang banyak disebut di media massa sekarang ini, tak pelak lagi itu adalah Jamaah Islamiyah (JI). Amerika Serikat (AS) memasukkan JI dalam Organisasi Teroris Asing (FTO).

Australia dan Singapura telah mengajukan proposal kepada Dewan Keamanan (DK) PBB agar memasukkan JI dalam daftar teroris internasional versi PBB. Proposal itu Kamis 
(24/10) lalu sudah didukung 30 negara, termasuk Indonesia.

Mereka menyebut JI mempunyai kaitan dengan jaringan terorisme internasional, kepanjangan tangan dari Alqaidah pimpinan Usamah bin Ladin. Berbagai peledakan bom di sejumlah negara, terutama di Asia Tenggara seperti di Filipina dan Indonesia - termasuk peristiwa terakhir peledakan bom di Bali-mereka sebut dilakukan JI. Singkat kata, JI merupakan 'makhluk' yang paling menakutkan dan membahayakan manusia. (Republika, 26/10/2002)

Republika juga memanfaatkan latar belakang untuk mengemukakan informasi dan opini tentang tudingan kepada JI ketika menanggapi peledakan bom di Hotel J.W. Marriott (5 Agustus 2003).

(14) Bola api bom JW Marriott menerpa umat Islam. Pejabat-pejabat di pemerintahan Megawati Soekarnoputri, terutama kepolisian, secara subjektif memberikan pernyataan tergesagesa sebelum ada hasil penyelidikan yang valid. Berbekal asumsi, mereka menyatakan pemboman hotel JW Marriott dilakukan kelompok Islam. (Republika, 11/8/2003)

(15) Setiap ada aksi teror, terutama peledakan bom, di Indonesia selalu dikaitkan dengan Jamaah Islamiyah (JI). Setelah tragedi bom Bali, kini JI dikaitkan dengan bom yang meledak di Hotel JW Marriott, Kuningan, Jakarta. Kali ini, sinyalemen berbau tuduhan itu secara buru-buru dilontarkan oleh jajaran kepolisian. (Republika, 15/8/2003)

\section{Kebiadaban Pelaku Teror dan Dampak Ledakan}

Informasi dan opini tentang kebiadaban pelaku teror dan dampak ledakan diajukan Republika dalam latar belakang WTT 7 Agustus 2003 (bom Marriott), 10 September 2004 (bom Kedubes Australia), dan 3 Oktober 2005 (bom Bali II).

(16) Siapa pun manusia waras tentu mengutuk pelaku peledakan bom di Hotel JW Marriott di kawasan Mega Kuningan, Jakarta, Selasa lalu. Mereka pasti menyatakan perbuatan itu sebagai biadab dan tak berperikemanusiaan.

Kalau tidak, adakah kata-kata lain untuk menyebut perbuatan yang telah menyebabkan belasan orang meninggal dunia dan puluhan lain lukaluka berat dan ringan? Mereka, para korban itu, adalah manusia-manusia tak berdosa yang, bisa dipastikan, tak ada sangkut-pautnya dengan pelaku peledakan bom. (Republika, 7/8/2003)

(17) Bom kembali mengguncang Jakarta, tepatnya di depan Kedutaan Besar Australia di Jl Rasuna Said, Jakarta Selatan. Ledakan tersebut tidak hanya menghancurkan gedung kedutaan, tetapi juga gedung bertingkat di sekelilingnya.

Ledakan bom kali ini juga memakan korban, setidaknya 8 orang tewas dan 88 luka-luka, baik berat maupun ringan. Ledakan ini sekaligus mengingatkan kita akan ledakan besar lainnya di Jakarta seperti di depan Kedubes Filipina, di lantai parkir basement BEJ, dan di halaman Hotel Marriott beberapa waktu lalu. (Republika, 10/9/2004)

(18) .... Begitu bom meledak, ratusan orang - baik domestik maupun asing - lari tunggang langgang karena panik. Apalagi pada Sabtu malam banyak turis yang sedang menikmati liburan di kawasan wisata di Bali ini. Selain menghancurkan bangunan, tiga ledakan bom itu juga telah menyebabkan 31 orang tewas, 26 di antaranya sudah teridentifikasi, dan 122 lainnya luka-luka. Mayoritas korban adalah warga Indonesia. (Republika, 3/10/2005) 
Latar belakang dalam kutipan (16) s.d. (19) menyatakan informasi tentang kebiadaban pelaku dan akibat ledakan bom di Hotel Marriott, di depan Kedubes Australia, dan di Jimbaran (bom Bali II). Pelaku peledakan dilukiskan biadab dan tak berperikemanusiaan. Dampak ledakan menyebabkan korban manusia serta rusaknya gedung-gedung dan bangunan. Informasi itu membuat pelakunya layak dikutuk, dan pelaku itu adalah intelijen AS dan sekutunya.

\section{Rekayasa Intelijen dan Pihak Asing}

Republika menempatkan intelijen asing sebagai dalang atau otak di balik aksiaksi teror bom. Tindakan teror merupakan permainan intelijen dan pihak asing. Permainan itu tidak melulu berupa peledakan bom, tetapi juga berwujud kejadian-kejadian yang terkesan dipaksakan (rekayasa). Misalnya, munculnya Umar Al-Faruq yang ditangkap dan ditahan tentara AS di penjara Guantanamo, Kuba, karena diduga sebagai anggota jaringan teroris JI.

(19) Rupanya orang yang disebut-sebut bernama Umar Al-Faruq adalah manusia super yang serba tahu. Pernyataan-pernyataannya yang selalu dilansir Badan Intelijen AS (CIA) laku keras di media internasional. Masuk akal atau tidak, tak soal benar. Juga tak dimasalahkan bahwa pernyataannya masih harus dibuktikan dulu. Misalnya jenis bom yang meledak di Legian, sementara para penyelidik - gabungan penyelidik nasional dan internasional, termasuk dari AS sendiri-masih belum menetapkan dengan pasti jenisnya, Faruk sudah dengan 'tegas' menyebutnya. Pokoknya, begitu muncul pernyataan Faruk - entah dari lubang mana ia berceloteh, apa pun wujudnya-langsung disambar media. Barangkali itu juga tak jadi soal, toh ada penyalur suaranya, ya
CIA itu. Apa benar CIA, entah pulalah itu. (Republika, 23/10/2002)

Republika kembali memanfaatkan latar belakang ketika menanggapi kesimpangsiuran pendapat tentang jenis bom yang meledak di Legian (bom Bali I), rencana Australia membuka kantor permanen intelijen di Indonesia, dan dominannya pembahasan terorisme dalam KTT APEC di Los Cabos, Meksiko.

(20) Sampai hari kedua belas, belum ada penjelasan pasti jenis bom yang meledak di Legian, Bali. Pejabat penyidik pun berbeda pendapat. Dari efek yang ditimbulkan, ada yang menduga bom yang diledakkan berjenis C4. Pendapat itu dibenarkan para ahli bom dan juga Pusat Laboratorium Forensik Mabes Polri.

Namun, tim penyidik dari Australian Federal Police $(A F P)$, Superintendent Brett Swan, mengatakan bahwa bom yang meledak di depan Sari Club adalah RDX seberat $50-100 \mathrm{~kg}$. Pendapat serupa juga dikemukakan Wakabahumas Mabes Polri, Brigjen Pol Edward Aritonang. Dalam jumpa pers dengan Swan, Aritonang membantah jenis bom itu C4.

Sebelumnya Duta Besar Amerika Serikat, Ralph L Boyce, tidak sependapat ketika disebutkan bahwa bom Legian adalah C4. Dia justru menyatakan jenis bom di Legian adalah ammonium nitrat. Bom ini low explosive berkekuatan 3.000 VOD (velocity of detonation), sepertiga dari kekuatan C4 atau setengah kekuatan TNT. (Republika, 24/10/2002)

(21) Kantor berita AFP Senin (21/10) lalu memberitakan Australia berencana membuka kantor permanen intelijen di Indonesia. Rencana itu disampaikan Jaksa Agung Australia Daryl Williams kepada parlemen negeri itu, beberapa hari setelah peledakan bom di Bali yang menewaskan pu- 
luhan warga Australia. (Republika, 25/10/2002)

(22) Sidang Kerja Sama Ekonomi Asia Pasifik (Asia Pacific Economic Cooperation - APEC) di Los Cabos, Meksiko, 15-27 Oktober telah selesai. Sebagaimana sidang tahun 2001 lalu, pembahasan para pemimpin tertinggi ini tidak lepas dari adanya terorisme global.

Pada KTT APEC kesembilan di Shanghai 2001 lalu, pembahasan mengenai terorisme sudah mendominasi sidang. Hal tersebut berkaitan dengan terjadinya serangan terhadap World Trade Center dan Pentagon pada 11 September 2001. Disinggung pula dalam sidang itu rencana serangan ke Afghanistan.

Dalam KTT di Los Cabos ini, pembicaraan para pemimpin tertinggi APEC juga masih didominasi oleh permasalahan terorisme global. Terutama terkait dengan pengeboman di Bali yang menewaskan 184 orang - sebagian besar orang asing pada 12 Oktober 2002. (Republika, 29/10/2002)

Aroma rekayasa yang ditangkap Republika dan dikemukakan sebagai latar belakang dalam tiga WTT di atas adalah adanya kejadian beruntun yang seolaholah sudah dirancang. Dalam (20), ada pendapat bahwa bom yang meledak di Legian berjenis C4. Bom jenis ini diproduksi di AS, Inggris, dan Jerman. Namun, pendapat itu (segera) dibantah oleh pihak penyidik dari Australia, Mabes Polri, dan pemerintah AS yang diwakili duta besarnya di Indonesia. Dalam data (21), Australia berencana membuka kantor permanen intelijen di Indonesia. Memang ada keterangan beberapa hari setelah peledakan bom di Bali yang menewaskan puluhan warga Australia. Namun, keterangan yang menewaskan puluhan warga Australia diutarakan justru untuk menyatakan secara ironis bahwa Australia telah tega mengorbankan warganya sendiri, sebagaimana telah dilakukan AS dalam Tragedi WTC, 11 September 2001. Adapun dalam (22), dikemukakan rekayasa yang dilakukan AS melalui KTT APEC di Shanghai maupun Los Cabos. APEC yang merupakan forum kerja sama ekonomi telah didominasi agenda pembahasan tentang terorisme.

Pada 7 Agustus 2003, Majelis Hakim Pengadilan Negeri Denpasar, Bali, menjatuhkan vonis mati kepada terdakwa pelaku bom Bali I, yakni Amrozi. WTT Republika edisi 8 Agustus 2003 mengemukakan latar belakang yang mengaitkan dua peristiwa itu. Republika menduga adanya permainan intelijen asing.

(23) Terdakwa bom Bali, Amrozi, sesuai tuntuan jaksa, Kamis (7/8) dijatuhi hukuman mati. Tiga hari sebelum putusan itu dijatuhkan oleh hakim, Selasa (5/8), sebuah bom yang karakter ledakannya mirip bom Bali meledak di hotel JW Marriott, Kuningan, Jakarta, menelan 14 korban jiwa dan melukai 149 orang.

Bom yang diledakkan di kawasan yang juga banyak dikunjungi warga asing itu seakan mengingatkan bahwa, meskipun cukup banyak yang ditangkap dan diadili, masih banyak teroris yang berkeliaran di negeri ini dan mengancam keselamatan umat manusia. Ledakan bom Kuningan itu seakan juga sengaja 'menyambut' pembacaan putusan hakim terhadap Amrozi, di Nari Graha, Denpasar, Bali. (Republika, 8/8/2003)

Ungkapan sebuah bom yang karakter ledakannya mirip bom Bali meledak di Hotel JW Marriott secara tidak literal menyatakan bahwa karena jenis bomnya mirip, layak diduga bahwa pelaku dan "otak" bom Bali I maupun bom Marriott pun sama. Tuduhan itu lalu diperkuat dua pernyataan lain yang digaris bawah. 
Ketika menanggapi teror bom di depan Kedubes Australia, 9 September 2004, melalui WTT 15 September 2004, Republika mengemukakan kecurigaan bahwa teror bom itu pun merupakan hasil rekayasa intelijen asing, termasuk kemungkinan intelijen Australia sendiri justru bermain dengan "mengorbankan" kedutaan besarnya di Jakarta. Dalam latar belakang WTT-nya, Republika menampilkan dugaan rekayasa informasi yang dilakukan PM Australia John Howard dan Menlu Alexander Downer untuk kepentingan politik pribadi menjelang pemilu di Australia.

(24) $\ldots .$.

Pihak oposisi Australia sendiri meragukan kebenaran pernyataan Howard maupun Downer. Mereka curiga bahwa kabar SMS itu cuma rekayasa menjelang pemilihan umum 9 Oktober, tak sampai sebulan lagi. ... (Republika, 15/9/2004)

\section{Simpati kepada Ba'asyir serta Amrozi, dkk.}

Frame yang digunakan Republika pada akhirnya terepresentasi dalam latar belakang WTT berupa ungkapan simpati kepada Ba'asyir serta Amrozi, dkk. Mereka mewakili ketidakberdayaan umat Islam yang teraniaya dan menjadi korban permainan intelijen AS dan sekutunya.

(25) Ada pendapat bahwa Ustaz Abubakar Ba'asyit bukanlah wakil umat Islam Indonesia. Pendapat itu bisa saja benar karena umat Islam Indonesia majemuk. Namun, perlakuan polisi terhadap Ba'asyir telah mengantarkan Ba'asyir sebagai wakil dari perasaan umat Islam, bahkan juga wakil dari hati nurani manusia yang beradab. (Republika, 30/10/2002)

(26) Kemarin, dini hari, tiga terpidana mati kasus bom Bali I telah dieksekusi oleh regu tembak dari Kepolisian Republik Indonesia (Polri). Mereka adalah Amrozi, Ali Ghufron, dan Imam Samudra. Kita mendoakan semoga segala dosa ketiga almarhum diampuni oleh Allah SWT. Semoga pula segala amal kebaikan mereka semasa hidup diterima oleh Sang Maha Pencipta. Kita juga mendoakan agar para anggota keluarga yang mereka tinggalkan diberi ketabahan, kesabaran, dan kemudahan dalam melanjutkan kehidupan. (Republika, 10/11/2008)

Sebagai koran Islam, dalam (25) Republika menampilkan latar belakang yang memuat informasi (bahkan sudah beropini) tentang keteraniayaan Ba'asyir. Hal itu lalu ditarik dalam konteks lebih luas dengan menyatakan Ba'asyir sebagai wakil dari perasaan umat Islam, bahkan juga wakil dari hati nurani manusia yang beradab. Adapun dalam (26), Republika lebih banyak memanjatkan doa bagi Amrozi, dkk. beserta keluarganya.

\section{Representasi Frame dalam Latar Bela- kang WTT Kompas dan Koran Tempo}

Kompas dan Koran Tempo memanfaatkan latar belakang sejumlah WTT-nya sebagai representasi frame "Dalang teror misterius; penanganan lebih penting". Informasi dan opini yang dikemukakan berkisar tentang (a) kedahsyatan aksi teror dan dampak ledakan serta (b) penanganan terorisme.

\section{Kedahsyatan Aksi Teror dan Dampak Ledakan}

Saat menanggapi peristiwa bom Bali I (12 Oktober 2002), Kompas dan Koran Tempo memanfaatkan latar belakang WTT 14 Oktober 2002 untuk mengutarakan kedahsyatan aksi teror dan dampaknya.

(27) Aksi teror di Pantai Legian Bali menewaskan 182 orang dan melukai lebih dari 300 orang lainnya. Korban kebanyakan wisatawan asing. Malam minggu itu mereka memadati Pantai Legian dan Diskotek Sari dan Paddy's. 
Kita tambahkan bahwa mereka yang menjadi korban adalah orang-orang yang tidak berdosa. Mereka tidak tahu segala urusan politik, tiba-tiba harus menjadi korban tewas maupun luka-luka. (Kompas, 14/10/2002)

(28) Setiap kali bom meledak di negeri ini, masyarakat hanya bisa sedih atas jatuhnya korban, cemas, takut kalaukalau bom lain meledak lagi di sekitar kita. Itu juga yang kita rasakan ketika bom menghancurkan puluhan bangunan di kawasan hiburan, hotel, dan wisata Legian, Bali, menjelang tengah malam Minggu kemarin ini. ....

Korban Legian, sampai Minggu siang, tercatat 187 orang. Jumlah ini sangat mungkin terus bertambah mengingat masih banyak korban yang dalam kondisi kritis. Yang paling kita sesali, selain saudara-saudara kita, banyak warga yang tewas dari empat negeri lain. (Koran Tempo, 14/10/2002)

Informasi dan opini tentang kedahsyatan aksi teror dan dampaknya kembali dikemukakan Kompas dan Koran Tempo saat menanggapi bom di Hotel Marriott, 5 Agustus 2003, sebagaimana termuat dalam tiga kutipan berikut ini.

(29) Alangkah dahsyat dan mengerikan aksi peledakan bom di Hotel JW Marriott, Kuningan, Jakarta Selatan. Ledakan itu luar biasa dengan daya rusak sangat besar. Sedikitnya 10 orang tewas dan puluhan lain cedera. Kerugian harta benda juga tidak sedikit. (Kompas, 6/8/2003)

(30) Kecuali lebih dari seratus orang korban luka parah yang dirawat di berbagai rumah sakit, sehari setelah teror bom yang diledakkan di Hotel JW Marriott Jakarta, kita saksikan upacara pengebumian para korban tewas, yang jumlah totalnya hingga saat ini 10 orang.
Pada aksi teror ini, kebanyakan korban warga biasa. Di antaranya empat pengemudi taksi, tiga petugas satpam, dan seorang pengemudi pribadi. Kebanyakan yang sedang makan siang pada hari itu pun adalah orang Indonesia. Korban orang asing satu orang tewas dan sekitar 10 yang luka-luka. (Kompas, 8/8/2003)

(31) Kita semua mengira, dan sangat berharap, tak ada lagi teror bom setelah Tragedi Legian, Bali, Oktober 2002. Tapi ternyata kita semua salah, serta keliru berharap. Sebuah ledakan bom besar di Hotel JW Marriott pekan ini mengguncang kesadaran kita lagi. Teror bom kali ini membuat kita bertanya-tanya lebih serius apa sebenarnya yang sedang terjadi dengan negeri ini dan sampai kapan gelombang teror seperti ini masih harus kita alami. (Koran Tempo, 7/8/2003)

Juga ketika menanggapi bom di Kedubes Australia, 9 September 2004, Kompas dan Koran Tempo mengemukakan kedahsyatan teror dan dampaknya.

(32) Bom meledak lagi, kali ini di depan Kedutaan Besar Australia di kawasan Kuningan, Jakarta. Bom diledakkan di depan Kedubes Australia, tetapi korbannya semua orang Indonesia. Jumlah korban tewas masih simpang siur, tetapi ada yang menyebut enam orang, sedangkan korban luka sekitar 100 orang. (Kompas, 10/9/2004)

(33) Sungguh suatu sasaran yang jitu, demikian pula dampak dan efeknya untuk membangkitkan perhatian domestik dan internasional. Sungguh serba diperhitungkan secara lihai. Sungguh tak peduli terhadap korban jiwa, apalagi korban hancurnya bangunan dan kaca. (Kompas, $11 / 9 / 2004)$

(34) Ucapan belasungkawa sedalamdalamnya disampaikan kepada para keluarga korban yang tewas dan 
siapa saja yang terluka dalam tragedi ledakan bom di depan Kedutaan Besar Australia di Jakarta kemarin. Ledakan bom itu termasuk yang terbesar terjadi di sini. Dan, kita, khususnya warga Jakarta, baru saja menyaksikan bagaimana jahatnya ledakan bom, dan betapa laknatnya pekerjaan para teroris. (Koran Tempo, 10/9/2004)

Begitu pula saat menanggapi teror bom di Jimbaran (bom Bali II), pada 1 Oktober 2005. Kedahsyatan aksi teror dan dampaknya dikemukakan dalam latar belakang WTT Kompas dan Koran Tempo pada kutipan (35) dan (36).

(35) Serangan di Bali yang kedua ini terjadi setelah serangan teror di Hotel Marriott dan di depan Kedubes Australia di Jakarta. Sampai sejauh ini, serangan teror 1 Oktober itu menewaskan 25 orang dan menyebabkan puluhan orang mengalami luka-luka. (Kompas, 3/10/2005)

(36) Tiga bom meledak di Jimbaran dan Kuta, Bali, akhir pekan kemarin. Sudah 22 orang tewas dan lebih dari seratus orang luka-luka, tapi sekarang yang perlu diselamatkan dari kerusakan lebih parah adalah Indonesia. (Koran Tempo, 3/10/2005)

\section{Penanganan Terorisme}

Frame yang dipilih Kompas dan Koran Tempo menempatkan penanganan lebih penting daripada memperdebatkan siapa pelaku (dalang) aksi terror.

(37) Pemerintah dan DPR sepakat tentang segera dikeluarkannya Peraturan Pemerintah Pengganti Undang-undang (Perpu) Antiterorisme oleh Presiden. Dengan keluarnya perpu itu, pemerintah mendapatkan payung hukum untuk menindak aksi teror secara efektif. (Kompas, 19/10/2002)

(38) Pekan ini, Presiden Megawati Soekarnoputri berangkat menuju Meksiko untuk menghadiri pertemuan puncak Kerja Sama Ekonomi Asia Pasifik (APEC). Apa yang akan dia dengar di situ? Apa pula yang seharusnya dia katakan kepada para pemimpin di sana? (Koran Tempo, 23/10/2002).

Terkait dengan teror bom di Hotel Marriott, 5 Agustus 2003, dua kutipan berikut ini menunjukkan latar belakang yang memuat informasi dan opini tentang penanganan.

(39) Aroma mesiu di Hotel JW Marriott, Jakarta, belum benar-benar sirna ketika radio $A B C$ Australia pada Kamis lalu menyiarkan wawancara dengan Brigjen Pol. Gorries Mere. Dalam wawancara itu ia menyatakan, polisi memperoleh informasi bakal terjadinya aksi bom bunuh diri enam pekan silam.

Menarik bahwa, dalam wawancara itu, Mere mengatakan, polisi telah menyadap surat elektronik dari seseorang bernama Asmal. "Dalam penyadapan kami, surat elektronik itu menyatakan, dia (Asmal) ingin 'menikah secepatnya'. Ini kata sandi yang biasa dipakai Jemaah Islamiyah, bahwa dia ingin melakukan aksi bunuh diri," kata Mere seperti dikutip media Australia itu. (Koran Tempo, 9/8/2003)

(40) Itulah pengamatan yang kita peroleh bahwa kita, bangsa Indonesia, tahan guncangan. Guncangan-guncangan yang menimpa sejak krisis lima tahun lalu dan juga guncangan yang diterpakan oleh aksi-aksi teror, yang terakhir peledakan bom di Hotel JW Marriott, Jakarta. Masa kini dan masa depan yang dekat ini masih akan berat. Tetapi, sebagai bangsa, rasanya kita akan mampu menghadapinya. (Kompas, 11/8/2003).

Dua contoh berikut ini memperlihatkan latar belakang WTT Kompas saat me- 
nanggapi bom Bali II (1 Oktober 2005) dan Koran Tempo untuk menanggapi tewasnya Dr. Azahari (9 November 2005). Keduanya menampilkan informasi dan opini tentang penanganan, yakni pemanfaatan semua kekuatan untuk melawan aksi teror dan masih banyaknya pekerjaan besar meski Azahari telah tewas.

(41) Ketika tahu orang yang dihadapi Komandan Korps Marinir, seorang duta besar segera bertanya, apa yang bisa dilakukan marinir untuk melawan aksi teror.

Sang duta besar pantas bertanya karena enam warganya menjadi korban aksi teror 1 Oktober 2005 di Bali. Ia paham tentang arti demokrasi karena negaranya juga menerapkan sistem demokrasi. Tetapi ia tidak paham mengapa di Indonesia, karena alasan demokrasi, tidak semua kekuatan yang dimiliki bisa dipakai untuk menghadapi terorisme, yang jelas-jelas merenggut nyawa begitu banyak orang yang tidak berdosa. (Kompas, 7/10/2005)

(42) Kalau sudah pasti Azahari yang tewas dalam penyerbuan oleh polisi di Batu, Jawa Timur, dua hari lalu, masih banyak pekerjaan besar tersisa. Tapi, sebelum melanjutkan pekerjaan besar lain, bolehlah kita berikan salut dan penghargaan yang tinggi atas keberhasilan polisi menumpas perakit bom yang dianggap paling berbahaya di Asia Tenggara itu. Seandainya Azahari bisa ditangkap hidup-hidup, tentu pujian kepada polisi makin bertambah-tambah. Tapi situasi lapangan agaknya tak memungkinkan penangkapan hiduphidup gembong bom yang dianggap berdiri di belakang meledaknya serangkaian bom di Bali dan Jakarta itu. (Koran Tempo, 11/11/2005)

\section{SIMPULAN}

Melalui kajian ini terbukti bahwa frame surat kabar tentang terorisme terepresentasi secara sistematis dalam bagian latar belakang wacana tajuk tentang terorisme (WTT). Suara Pembaruan menggunakan frame "Dalang teror adalah Jemaah Islamiyah dan jaringannya; motifnya melakukan kekerasan dengan mengatasnamakan Islam". Frame itu kemudian direpresentasikan dalam latar belakang WTT dalam wujud informasi dan opini tentang (a) Indonesia menjadi korban terorisme, (b) kebiadaban aksi teror dan dampak ledakan, (c) isyarat tentang pelaku teror, serta (d) Azahari dan Amrozi, dkk. sebagai teroris.

Republika menggunakan frame "Dalang teror adalah intelijen AS dan sekutunya; motifnya menguasai sumber daya alam Indonesia dengan memojokkan Islam." Frame tersebut lalu direpresentasikan dalam latar belakang WTT sebagai informasi dan opini tentang (a) tudingan terhadap JI, (b) kebiadaban pelaku teror dan dampak ledakan, (c) rekayasa intelijen dan pihak asing, serta (d) simpati kepada Ba'asyir serta Amrozi, dkk.

Sementara itu, Kompas dan Koran Tempo menggunakan frame "Dalang teror misterius; penanganan lebih penting". Frame itu lalu direpresentasikan dalam latar belakang sebagai informasi dan opini tentang (a) kedahsyatan aksi teror dan dampak ledakan serta (b) penanganan terorisme.

\section{UCAPAN TERIMA KASIH}

Artikel ini merupakan sebagian dari hasil penelitian berjudul "Frame Surat Kabar Nasional tentang Terorisme: Analisis Pragmatik Kritis mengenai Fenomena Terorisme di Indonesia 2002-2013" yang didanai dengan skema penelitian Fundamental tahun anggaran 2014-2015. Oleh karena itu, penulis mengucapkan terima kasih kepada Direktorat Riset dan Pengabdian kepada Masyarakat, Ditjen 
Penguatan Riset dan Pengembangan, Kemenristek Dikti atas bantuan dana dan pendampingannya. Selain itu, ucapan terima kasih penulis sampaikan kepada pengelola jurnal Litera dan para reviewer yang telah membaca, mengoreksi, dan memberikan masukan untuk perbaikan artikel ini.

\section{DAFTAR PUSTAKA}

Ardianto. 2015. "Struktur Argumen dalam Wacana Karya Tulis Ilmiah Mahasiswa". Dalam Jurnal Litera, Fakultas Bahasa dan Seni, Universitas Negeri Yogyakarta, Volume 14, Nomor 1, April 2015, hlm. 1-10.

Bolivar, A. 1994. "The Structure of Newspaper Editorials", dalam M. Coulthard (ed.). Advances in Written Text Analysis. London: Routledge, hlm. 276-294.

Eriyanto. 2002. Analisis Framing: Konstruksi, Ideologi, dan Politik Media. Yogyakarta: LKIS.

Fairclough, N. 1995. Media Discourse. London and New York: Arnold.

Fairclough, N. 2010. Critical Discourse Analysis: The Critical Study of Language. Edisi Kedua. Harlow: Pearson.

Koesworo, F.X.; Y.B. Margantoro; dan R.S. Viko. 1994. Di Balik Tugas Kuli Tinta. Surakarta: Sebelas Maret University Press dan Yayasan Pustaka Nusatama.

Leech, G. 1983. Principles of Pragmatics. Singapore: Longman.

Oddo, J. 2011."War Legitimation Discourse: Representing 'Us' and 'Them' in Four US Presidential Addresses". Dalam Jurnal Discourse \& Society, Volume 22, 3, Mei 2011, hlm. 287-314.

Renkema, J. 2004. Introduction to Discourse Studies. Amsterdam/ Philadelphia: John Benjamin Publishing Company.

Salama, A.H.Y. 2011. "Ideological Collocation and the Recontexualization of Wahhabi-Saudi Islam Post-9/11: A Synergy of Corpus Linguistics and Critical Discourse Analysis". Dalam
Jurnal Discourse E Society, Volume 22, 3, Mei 2011, hlm. 315-342.

Sampson, G. 1980. Schools of Linguistics. London: Hutchinson.

Subagyo, P.A. 2009. “Tiga Pendekatan dalam Analisis Wacana". Dalam Jurnal Widyaparwa, Volume 37, Nomor 2, Desember 2009, hlm. 133-152.

Subagyo, P.A. 2010. "Pragmatik Kritis: Paduan Pragmatik dengan Analisis Wacana Kritis". Dalam Jurnal Linguistik Indonesia, Tahun Ke-28, Nomor 2, Agustus 2010, hlm. 177-188.

Subagyo, P.A. dan S.E.P. Adji. 2014. "Frame Surat Kabar Nasional tentang Terorisme: Analisis Pragmatik Kritis atas Editorial mengenai Fenomena Terorisme di Indonesia 2002-2013". Laporan Penelitian (Tahun I) Hibah Fundamental kepada DP2M Direktorat Pendidikan Tinggi, Kemendiknas.

Sudaryanto. 2015. Metode dan Aneka Teknik Analisis Bahasa: Pengantar Penelitian Wahana Kebudayaan secara Lingustis. Yogyakarta: Sanata Dharma University Press.

Titscher, S.; M. Meyer; R. Wodak; dan E. Vetter. 2000. Methods of Text and Discourse Analysis. London: SAGE Publications.

van Dijk, T.A. 1995a. "Structures of News in the Press". Dalam T.A. van Dijk (ed.) Discourse and Communication: New Approaches to the Analysis of Mass Media Discourse and Communication. New York: Walter de Gruyter.

van Dijk, T.A. 1995b. “Opinions and Ideologies in Editorials". Makalah dalam The $4^{\text {th }}$ International Symposium of Critical Discourse Analysis, Language, Social Life, and Critical Thought, Athena, 14-16 Desember 1995. Diunduh dari http://www.discourse-in-society. org//teun.html, pada 23 Januari 2011. van Dijk, T.A. 1996. "Discourse, Power and Access". Dalam C.C. Coulthard dan M. Coulthard (eds.). Texts and 
Practices: Readings in Critical Discourse Analysis. London: Routledge, hlm. 84-104.

van Dijk, T.A. 2005. "Contextual Knowledge Management in Discourse Production: A CDA Perspective". Dalam R. Wodak dan P. Chilton (eds.). 2005. A New Agenda in (Critical) Discourse Analysis. Amsterdam/Philadelphia: John Benjamins, hal. 71-100. van Dijk, T.A. 2006. "Multidisciplinary CDA: A Plea for Diversity". Dalam R. Wodak dan M. Meyer (eds.). 2006. Methods of Critical Discourse Analysis. London: Sage, hlm. 95-120.

van Dijk, T.A. 2010. “Critical Discourse Studies: A Sociocognitive Approach". Dalam R. Wodak dan M. Meyer (eds.). 2006. Methods of Critical Discourse Analysis. Edisi Kedua. London/California/New Delhi/Singapura: Sage, hlm. 62-86. 